\title{
Application of growing degree days for mango hopper population dynamics at Lucknow, U.P.
}

\author{
GUNDAPPA*, TARUNADAK and P.K. SHUKLA \\ ICAR-Central Institute for Subtropical Horticulture, Rehmankhera, Lucknow-226101, Uttar Pradesh, India \\ *Corresponding author: gundappa@icar.gov.in
}

\begin{abstract}
Mango hopper population dynamics at different phenological stages was predicted using the growing degree days (GDD) of mango during 2013, 2014 and 2015 under Lucknow climatic conditions. Results revealed that at the time of flowering,there was wide variations in hopper infestation level during three consecutive seasons. Identical trend was observed at early flowering (30 per cent of panicle flowers open), full flowering (more than 50per cent of panicle flowers open), full flowering (all petals fallen or dry) and from fruit set to physiological fruit maturity. The relationship between the GDD and hopper population was established by linear regression analysis and it was inferred that the GDD had explained variation in hopper population upto 66 per cent across the three seasons. Thus, growing degree days served as a basis for predicting hopper population at different phenological stages of mango.
\end{abstract}

Key words : Phenological stages, mango, mango hopper, growing degree days

Mango (Mangifera indica L.), one of the major fruit crops of India, is known as the king of fruits for its sweetness, excellent flavour, delicious taste and high nutritive value. Mango is infested by several insect pests during its growth and development. Among the insect pests mango hoppers cause heavy damage to crop during flowering and fruiting stage, resulting in 25-60 per cent yield loss (Munjet al., 2017). Degree-day based models are very useful in predictions as development of insects and plants is temperature-dependent and predict the biological phenomenon at most accuracy (Mussey and Potter 1997). Daily maximum and minimum temperatures undergoes great variation and seasonal dynamism also influences fruits production (Adak et al., 2017). The variation in the temperature influences the mango hopper population positively (Pandey et al. 2003; Zagade and Chaudhari,2010). Therefore in this study emphasis was given to use the growing degree days (GDD) or accumulated heat units of mango derived from the prevailing maximum and minimum temperature, for appraisal of the hopper population.

\section{MATERIALS AND METHODS}

The study was carried out in the twenty two mango orchards (cv.Dashehari) aged between 22-35 years for three seasons (2013, 2014 and 2015). Data on the incidence of hoppers on leaves/panicle/trunk were recorded on weekly basis from five randomly selected trees by net sweeping method and expressed as number of hopper per sweep. Mean population of hopper per standard meteorological week was taken into consideration for the further analysis. Data on the mango phenology was collected based on the modified Biologische Bundesantalt, Bundessortenamt and Chemische Industrie (BBCH) scale of phenological stages developed by Rajan et al. (2011). The start in inflorescence emergence in mango is described by the scale 510 , beginning of bud swelling-511, bud bursting-513 and so on so forth. The flowers visibility indicated by the scale 515 to 517 with the end of panicle development as 519. The principal flowering stages described as 610 to 617 with first flower open-610,30 per cent flowering- 613 and more than 50 per cent flowering -615 . The fruit set in mango is described by $619 \mathrm{BBCH}$ scale.

Daily weather data of temperature (maximum and minimum), relative humidity (morning and evening), rainfall, wind speed, bright sunshine hours and evaporation rates were recorded in the Agromet Observatory located within the experimental site. Growing degree days (GDD) were calculated as follows:

Growing degree days (GDD) $=\Sigma\left(\mathrm{T}_{\text {Max }}+\mathrm{T}_{\text {Min }}\right) / 2-\mathrm{T}_{\text {Base }}$

Where, $\mathrm{T}_{\mathrm{Max}}$ and $\mathrm{T}_{\text {Min }}$ are the maximum and minimum temperatures $\left({ }^{\circ} \mathrm{C}\right)$ of the day and $\mathrm{T}_{\text {Base }}$ is base temperature which was taken as $15^{\circ} \mathrm{C}$ (Whiley et al., 1991). Growing 
Table 1: Population dynamics of mango hopper and growing degree days of mango at different phenological stages during 2013 to 2015.

\begin{tabular}{llllllll}
\hline Phenological stage (BBCH Scale) & \multicolumn{2}{l}{ Hopper population (number/sweep) } & & \multicolumn{3}{c}{ Growing degree days $\left({ }^{\circ} \mathrm{Cd}\right)$} \\
\cline { 2 - 3 } \cline { 6 - 7 } & 2013 & 2014 & 2015 & & 2013 & 2014 & 2015 \\
\hline Inflorescence emergence (510) & 0.00 & 0.20 & 0.79 & & 645 & 762 & 676 \\
Beginning of bud swelling (511) & 0.58 & 0.21 & 0.25 & & 644 & 764 & 671 \\
Bud burst (513) & 0.58 & 0.21 & 0.25 & & 650 & 765 & 674 \\
Panicle axis begin to elongate (514) & 0.43 & 0.30 & 0.12 & & 650 & 765 & 674 \\
Flowers visible(515-517) & 0.43 & 0.30 & 0.12 & & 654 & 758 & 695 \\
End of panicle development(519) & 1.00 & 0.23 & 0.41 & & 654 & 758 & 695 \\
First flower open (610) & 0.31 & 0.74 & 1.47 & & 673 & 768 & 735 \\
Flowering 50 per cent (613) & 3.68 & 1.32 & 2.42 & & 713 & 786 & 762 \\
Flowering 100 per cent (615) & 3.68 & 1.32 & 2.42 & & 758 & 817 & 792 \\
Fruit set (619) & 5.10 & 1.84 & 3.40 & & 758 & 817 & 792 \\
\hline
\end{tabular}

degree days were computed on daily basis taking $1^{\text {st }}$ September as base for each year since mango is harvested during June and July in Northern India and post harvest vegetative phase started. However, weekly mean data was taken into consideration for the further analysis. Statistical analysis that is correlation and regression was carried out using MS Excel and SPSS package (Version 16.0).

\section{RESULTS AND DISCUSSION}

\section{Mango hopper population}

At different phenological stages the hopper population varied significantly. From beginning of bud swelling (scales begin to separate) to full flowering, the hopper population ranged from 0.2 to $3.68,0$ to 1.32 and 0.79 to 2.42 hopper/sweep during the year 2013,2014 and 2015 respectively (Table 1).It was inferred from the study that mango hopper population emergence was coincided with the emergence of new flushes and panicles. In general, hoppers remain active throughout the year in cracks and crevices of mango trunk, but they were observed on twigs, when young leaves and inflorescence are available (Gundappa et al., 2014). The peak occurrence of the population was observed between second week of March to last week of May.

\section{Growing degree days (GDD)}

Growing degree days (GDD) of mango followed sigmoid pattern and it ranged from 51 to $3136^{\circ} \mathrm{Cd}$ from bud differentiation to physiological fruit maturity across the three seasons. From beginning of bud swelling (scales begin to separate) to fruit set the GDD varied significantly and ranged from 645 to 758,762 to 816,676 to $792^{\circ} \mathrm{Cd}$ during the year 2013, 2014 and 2015 respectively (Table 1).

\section{Relationship between growing degree days (GDD) and hopper population}

The relationship between the GDD and hopper population was established by linear regression analysis and it was inferred that the GDD had explained variation in hopper population significantly. GDD had followed liner relationship with hopper population across the three years (hopper population $=0.019 \mathrm{x}-12.60 ; \mathrm{R}^{2}=0.662$ ) and had explained 66 per cent variation in hopper population (Fig.1).Successful implementation of integrated pest management strategies for mango requires accurate prediction of hopper population at different phenological stages. It is generally understood that weather variables such as temperature, humidity, are important abiotic variables that influence hopper population dynamics (Pandey et al. 2003; Zagade and Chaudhari, 2010). However, apart from abiotic variables, many biotic variables such as host plants can also play an important role in hopper emergence and development (Gundappa et al., 2014). In the present study, GDD had explained considerable variation in the hopper population over the years. Mussey and Potter (1997) also opined that plant phenological sequences could be used as reliable indicators for predicting insect activity from yearto-year with greater consistency compared to weather which exhibits tremendous variation. Thus, growing degree days may serve as basis for predicting hopper population at different phenological stages of mango. 


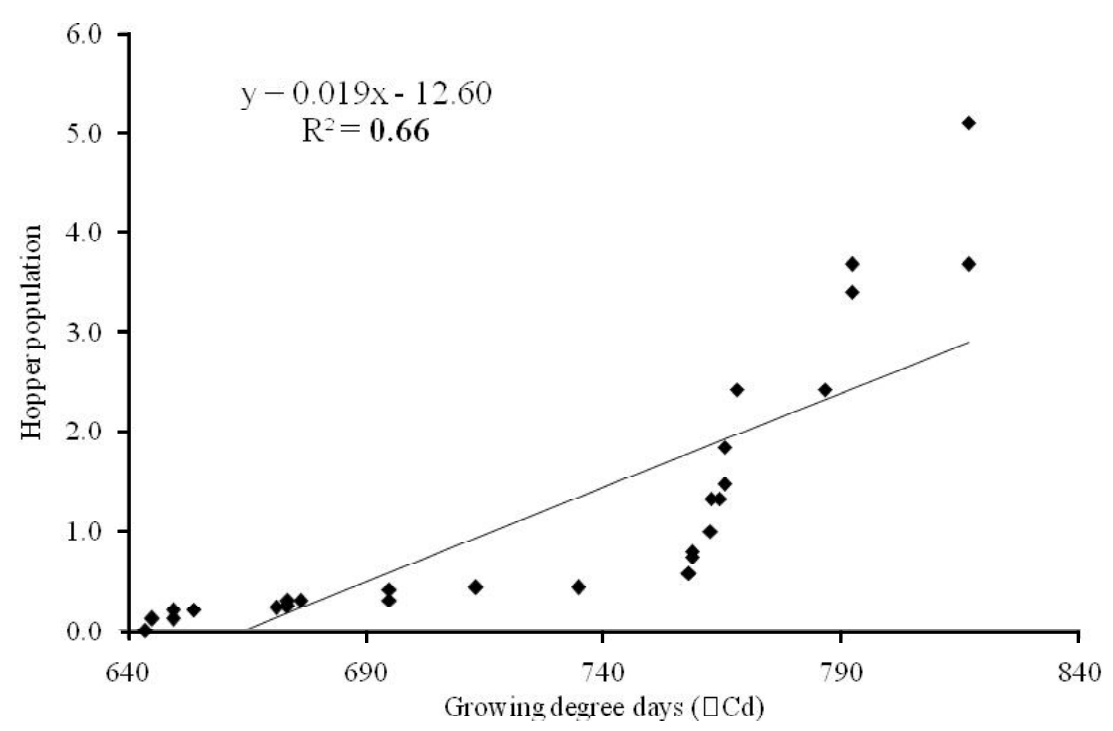

Fig1: Relationship between growing degree days of mango and peak hopper population.

\section{CONCLUSION}

The relationship between the GDD and hopper population was established by linear regression analysis and it was inferred that the GDD had explained variation in hopper population upto 66 per cent cutting across the three seasons. Thus, growing degree days served as a basis for predicting hopper population at different phenological stages of mango.

\section{ACKNOWLEDGEMENTS}

Authors are thankful to the Director, CISH, Lucknow for providing facilities for carrying out the work. Thanks are also due to Indian Council of Agricultural Research, New Delhi for providing financial assistance underNational Initiative of Climate Resilient Agriculture (NICRA) Project entitled, "Understanding the changes in host pest interactions and dynamics in mango under climate change scenario", which facilitated carry out this study.

\section{REFERENCES}

Adak, T., Kumar, K. and Singh, V.K. (2017). Assessment of thermal heat requirement, radiation energy, water use efficiency, and yield of mango cvDashehari using fertigation method. J. Agrometeorol., 19(1):44-50.

Gundappa., Kamala Jayanthi,P.D. and Verghese, A. (2014). Migratory behaviour of mango hopper, Idioscopus spp. In relation to host plant flowering phenology: A synchronous shift. An International J. Life Sci.: The Bioscan, 9(2): 639-641.
Mussey, G.J. and. Potter,D.A. (1997). Phenological correlations between ûowering plants and activity of urban landscape pests in Kentucky. J. Econ. Entomol., 90: 1615-1627.

Munj, A.Y., Rana, B.S. and Godase, S.K. (2017). Population dynamics of mango hopper, Idioscopus niveosparsus Leth and its natural enemies under coastal Konkan conditions of Maharashtra. J. Agrometeorol.,19(4):373375 .

Pandey, V., Patel, M.G., Chaudhari, G.B., Patel, J.R., Bhatt, B.K., Vadodaria, R.P. and Shekh, A.M. (2003). Influence of weather parameters on population dynamics of mango hopper. J. Agrometeorol., 5(1):51-59.

Rajan, S. Tiwari, D., Singh, V.K., Saxena, P., Singh, S., Reddy, Y.T.N.,Upreti, K.K., Burondkar, M.M., Bhagwan,A. and Kennedy, R. (2011). Application of extended BBCH scale for phenological studies in mango (Mangifera indica L.). J. Appl. Hort., 13(2): 108-114.

Whiley, A.W., Rasmussen, T.S., Wolstenholme, B.N., Saranah. J.B. and Cull B.W. (1991). Interpretation of growth responses of some mango cultivars grown under controlled temperature. Acta Hort., 291: 22-31.

Zagade, M.V. and Chaudhari, J.N. (2010). Impact of meteorological parameters on population dynamics of mango hopper in high rainfall zone of Konkan region. $J$. Agrometeorol., 12(1):111-113 